\title{
Cytotoxic activity of seaweeds from North Sulawesi marine waters against cervical cancer
}

\author{
Grace Sanger $^{1 *}$, Lexy Karel Rarung ${ }^{2}$, Djuhria Wonggo ${ }^{1}$, Verly Dotulong ${ }^{1}$, Lena Jeane Damongilala ${ }^{1}$, Trina Ekawati Tallei ${ }^{3}$ \\ ${ }^{1}$ Department of Fishery Product Technology, Faculty of Fishery and Marine Science, Sam Ratulangi University, Manado, Indonesia. \\ ${ }^{2}$ Department of Fishery Social Economic, Faculty of Fishery and Marine Science, Sam Ratulangi University, Manado, Indonesia. \\ ${ }^{3}$ Department of Biology, Faculty of Mathematics and Natural Sciences, Sam Ratulangi University, Manado, Indonesia.
}

\begin{tabular}{l}
\hline ARTICLE INFO \\
\hline Received on: 15/04/2021 \\
Accepted on: 08/06/2021 \\
Available online: 05/09/2021 \\
\\
\hline Key words: \\
Cervical cancer, HeLa \\
cells, antioxidant, seaweed, \\
cytotoxicity, North Sulawesi.
\end{tabular}

\section{INTRODUCTION}

Carcinoma of the uterine cervix is the most common type of female cancer worldwide. According to data from the Globocan project, the total number of new cancer cases was estimated to be 604,127 in 2020 , with 341,831 deaths. The most common case was squamous cell carcinoma, followed by adenocarcinomas. In Indonesia, there are 95.9 million women at risk of cervical cancer, with 32,469 new cases diagnosed each year and 18,297 deaths (Bray et al., 2018).

\footnotetext{
*Corresponding Author

Grace Sanger, Department of Fishery product Technology, Faculty of Fishery and Marine Science, Sam Ratulangi University, Manado, Indonesia.E-mail: sanger.grace@unsrat.ac.id
}

The human papillomavirus (HPV) is the main causal agent for all cases of cervical cancer, which is a malignant tumor that develops in the female reproductive organs, including the upper genital tract, uterus, and vagina. In the early stages of cervical cancer, this disease usually shows no symptoms with unusual vaginal bleeding ( $\mathrm{Pal}$ and Kundu, 2019). The human papillomavirus (HPV) has been studied as an extremely common virus that can be easily transmitted via sexual contact, regardless of sex. The extreme risk strains particularly are HPV-16 and 18 subtypes, which are identified to be accountable for more than $70 \%$ of the cases (Wang et al., 2014).

Numerous medications have been made to cure cancer including surgery, chemotherapy, radiotherapy, and targeted therapy. But all of these therapeutic procedures result in an unfavorable impact on the sufferer, such as pain, suffering, anemia, 
weakness, and a decrease in the immune system; after all, these treatments require high costs, because of imported medicines (Ajdari et al., 2016). As a result, novel innovations are required to provide medications derived from natural products, which are abundant in Indonesia and contain antiproliferative components against cancer cells. Marine-derived products and derivatives have been shown to have anticancer activity via a variety of cellular and molecular mechanisms (Ecorlano et al., 2019; Handayani et al., 2019, 2020; Sandrawati et al., 2020).

Seaweeds contain several sources of bioactive compounds, which have important health values. Some of the bioactive ingredients contained in seaweed are phenolic compounds, polysaccharides, Polyunsaturated fatty acids (PUFAs), proteins, vitamins, and minerals. These compounds display biological activities and potential for the use of drugs against cancer, tumors, thrombosis, diabetes, inflammation, and other degenerative diseases (Debbarama et al., 2016; Ganesan et al., 2019; Praiboon et al., 2018).

The continuous attack of reactive oxygen species on DNA is a significant cause of cancer development. Cells reduce oxidative stress either by repairing damaged nucleotides and lipid peroxidation byproducts or by directly reducing the prooxidative state via enzymatic and nonenzymatic antioxidants. Based on several research results on experimental animals showing that seaweed can reduce the risk of cancer involving cell proliferation and antioxidant activity (Bayro et al., 2021), consumption of seaweed has been shown to increase antioxidant enzymes (endogenous antioxidants) such as superoxide dismutase, glutathione peroxidase, and sometimes also catalase activity in vivo (Corsetto et al., 2020; Korivi et al., 2019).

Numerous macroalgae exhibit cytotoxic potential, and some experts recommend algae consumption as a preventative chemoagent for several types of cancer (Taskin et al., 2010). Many bioactive seaweeds show cytotoxic activity against cervical cancer cells (HeLa/SiHa cells), including 25-hydroperoxy$6 \beta$-hydroxycholesta-4,23(E)-dien-3-one, from the green algae Galauxaura marginata (Majumder et al., 2015), lectins from the red algae Eucheuma serra, and bis(2,3-dibromo-4,5dihydroxybenzyl) ether from the brown algae Leathesia nana (Ercolano et al., 2019).

Currently, marine products and their derivatives are widely used, not only as a health food but also in clinical medicine to prevent and treat cancer (Gomes et al., 2015). Seaweed has been shown to lessen the risk of cancer development in experimental animals, possibly through its antioxidant activity. The anticancer activity mechanism mediated by algae is extremely complex, owing to the astounding structural variations that result in multiplicative interactions (Namvar et al., 2012).

Natural products with apoptotic activity have garnered considerable interest in the search for alternative anticancer and complementary cancer prevention and treatment agents (Kim and Wijesekara, 2010). Seaweed powder or extract supplementation has been shown to reduce cell proliferation in in vitro test and animal studies (Gomes et al., 2015). The world's greatest diversity of seaweed species can be found in Indonesia. Moreover, Indonesian seaweed is relatively unexploited in relation to finding biologically active compounds. The antioxidant activity in this work was studied by cytotoxic assessment, especially by inhibitory concentration $\left(\mathrm{IC}_{50}\right)$. In this report, we examined five different types of tropical seaweed to determine the efficacy of their antiproliferative properties inducing cell death in preparation for potential future applications as novel cancer therapy agents.

\section{MATERIALS AND METHODS}

\section{Material}

HeLa $\quad\left(\right.$ ATCC $^{\circledR} \quad$ CCL-2 $\left.{ }^{\mathrm{TM}}\right)$ cell lines, 3-(4,5-dimethylthiazol-2-yl)-2-5-diphenyltetrazolium bromide (MTT), and dimethyl sulfoxide (DMSO) were purchased from Sigma Chemical Company (St. Louis, MO). Cell culture medium components Dulbecco's Modified Eagle Medium (DMEM) were obtained from Gibco (USA); fetal bovine serum (FBS) was obtained from HyClone (USA); penicillin and streptomycin were obtained from Invitrogen (USA); phosphate buffer saline (PBS) and trypsin were purchased from Gibco (USA); and ethanol was obtained from Merck (Germany). All other solvents and chemicals were of analytical grade.

\section{Seaweed extracts preparation}

Four seaweed species including Gracilaria salicornia, Turbinaria decurrens, Halimeda macroloba, and Laurencia tronoi were collected along the coast of North Sulawesi, Indonesia. The seaweeds were rinsed with clean seawater and cut into small parts. Five hundred grams of a sample was suspended in $1 \mathrm{Ll}$ of ethanol and shaken for 24 hours in the dark. The solvent extracts were then filtered and rotary-evaporated at $40^{\circ} \mathrm{C}-50^{\circ} \mathrm{C}$. The ethanol extracts (EE) were dissolved in DMSO and kept at $4^{\circ} \mathrm{C}$ until used. Before use, a stock solution of EE $(20 \mathrm{mg} / \mathrm{ml})$ was made by dissolving it in 50\% methanol and then diluted using DMEM in order to achieve the desired final concentration of $0.5 \%(\mathrm{v} / \mathrm{v})$.

\section{Analysis of cytotoxicity activity}

The MTT assay was used to determine EE's cytotoxicity activity, as formerly expressed by Gomez et al. (2015). The MTT assay is based on MTT reduction to a purple formazan product by viable cell mitochondrial dehydrogenases. HeLa (ATCC ${ }^{\circledR}$ CCL$2^{\mathrm{TM}}$ ) cell lines were grown in DMEM which was added with $10 \%$ FBS supplemented with $100 \mathrm{U} / \mathrm{ml}$ of penicillin and $100 \mu \mathrm{g} / \mathrm{ml}$ of streptomycin. The cells were nourished in monolayer cultures at $37^{\circ} \mathrm{C}$ in a humidified atmosphere containing $5 \% \mathrm{CO}_{2}$. HeLa cells were seeded in $75 \mathrm{~cm}^{3}$ flasks at a density of $5 \times 10^{6}$. Afterward, the HeLa cells were harvested and seeded into 96-well plates at a density of $5 \times 10^{3}$ cells/well in $100 \mu \mathrm{l} \mathrm{FBS}$ free medium and then incubated for 24 hours at $37^{\circ} \mathrm{C}$, with $5 \% \mathrm{CO}_{2}$. The medium was subsequently detracted and $100 \mu \mathrm{l}$ test solution (EE) in diverse concentrations and $100 \mu \mathrm{l}$ of medium containing 5\% FBS (MM) were added to the plate. Cells were grown under these conditions for 72 hours at $37^{\circ} \mathrm{C}$ with $5 \% \mathrm{CO}_{2}$. Cells grown using only MM were served as controls. After incubation, traces of EE were removed from the cells by washing them twice with $2001 \mathrm{PBS}$, adding $0.125 \%$ trypsin, and applying MTT ( $5 \mathrm{mg} / \mathrm{ml}$ ) which was dissolved in 1001 of fresh medium to examine the effects of the $\mathrm{EE}$ on cell viability. Cells were further incubated at $37^{\circ} \mathrm{C}$ for 4 hours with $5 \% \mathrm{CO}_{2}$. The product of MTT formazan was dissolved in $100 \mu \mathrm{l}$ ethanol and then the absorbance was calculated at the wavelength $570 \mathrm{~nm}$ in a Multiscan Ascent Microplate Reader. 


\section{Total phenolic content (TPC)}

The TPC of the extracts was measured using the FollinCiocalteu reagent according to Sanger et al. (2019). Briefly, 75\% of Folin--Ciocalteu's phenol reagent $(1 \mathrm{ml})$ was added to $0.1 \mathrm{ml}$ of extract ( $0.1 \mathrm{~g}$ dry sample in $10 \mathrm{ml}$ methanol) and vortexed. Then, after adding $1 \mathrm{ml}$ of $7 \% \mathrm{Na}_{2} \mathrm{CO}_{3}$, the solution was incubated for 30 minutes at room temperature. A spectrophotometer (Shimadzu type 1240, Tokyo, Japan) was used to measure absorbance at 750 $\mathrm{nm}$. TPC was expressed as $\mu \mathrm{g}$ gallic acid equivalent (GAE)/g extract.

\section{1,1-diphenyl-2-picrylhydrazyl (DPPH) radical scavenging activity assay}

The extracts' DPPH-scavenging capacity was determined by the antioxidants' ability to scavenge stable DPPH radicals using the method provided by Sanger et al. (2019). In brief, $2 \mathrm{ml} 0.93 \mathrm{M}$ DPPH was mixed with $0.5 \mathrm{ml}$ extract at various dilutions. The mixture was then vortexed and incubated at room temperature for 20 minutes. A spectrophotometer (Shimadzu type 1240, Tokyo, Japan) was used to measure the absorbance at 517 $\mathrm{nm}$. The experiment included the use of vitamin $\mathrm{C}$ as a positive control. Antioxidant activity was quantified as a percentage of DPPH-scavenging activity in comparison to a control.

\section{Ferric reducing antioxidant power (FRAP)}

The seaweeds extract antioxidant activities at various dilutions were determined by using FRAP assay following the method provided by Sanger et al. (2019). One ml 0.2 M phosphate buffer $(\mathrm{pH} 6.6)$ and $1 \mathrm{ml}$ of $\mathrm{K}_{3}\left[\mathrm{Fe}(\mathrm{CN})_{6}\right](1 \%)$ were mixed with $1 \mathrm{ml}$ extracts. After 20 minutes of incubation at $50^{\circ} \mathrm{C}, 1 \mathrm{ml} 10 \%$ trichloroacetic acid was applied to the solution and centrifuged for 10 minutes at 3,000 rpm. Afterward, $1 \mathrm{ml}$ of upper layer of the reaction mixture was added to $1 \mathrm{ml}$ sterile water and $0.5 \mathrm{ml}$ of $0.1 \%$ of $\mathrm{FeCl}_{36} \mathrm{H}_{2} \mathrm{O}$. The absorbance was measured using a spectrophotometer at $700 \mathrm{~nm}$. Butylated hydroxytoluene (BHT) served as a positive control. The FRAP value was expressed as $\mathrm{uM} \mathrm{Fe}{ }^{2+} / \mathrm{mg}$ extract.

\section{Statistical analysis}

All data are presented as mean \pm standard deviation. Using linear regression, the $50 \% \mathrm{IC}_{50}$ was calculated. The data were analyzed by Microsoft Excel 2010 version.

\section{RESULTS AND DISCUSSIONS}

\section{Anticervical cancer activity}

One of the methods commonly used to test the antiproliferative activity of anticancer drugs and chemopreventive compounds in vitro is the MTT method. This method is based on the reduction reaction of MTT (3-(4,5-dimethylthiazole-2yl)-2,5-diphenyltetrazolium bromide) which is catalyzed by the enzyme succinate dehydrogenase in human cells (Maioli et al., 2009; Namvar et al., 2014; Sylvester, 2011). The results of the cytotoxicity tests and cellular morphological changes revealed that EE of all four seaweed species had cytotoxicity activity against cervical cancer cell lines (Figs. 1 and 2). The cytotoxic activity $\left(\mathrm{IC}_{50}\right)$ of the extract against HeLa cell was 432.63, 41.027,

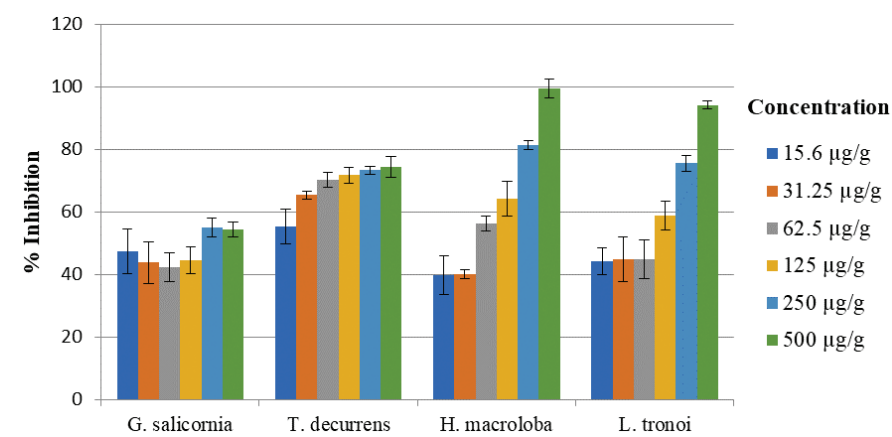

Figure 1. The cytotoxic activities of G. salicornia, T. decurrens, H. macroloba, and $L$. tronoi against HeLa cells $(15.6,31.25,62.5,125,250$, and $500 \mu \mathrm{g} / \mathrm{g})$.

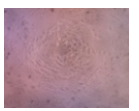

$15.6 \mu \mathrm{g} / \mathrm{g}$

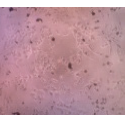

$15.6 \mu \mathrm{g} / \mathrm{g}$

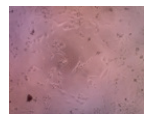

$31.25 \mu \mathrm{g} / \mathrm{g}$

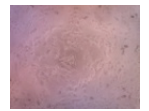

$62.50 \mu \mathrm{g} / \mathrm{g}$

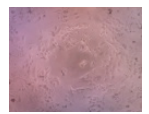

$125 \mu \mathrm{g} / \mathrm{g}$

G. salicornia

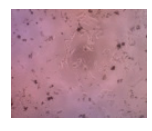

$62.50 \mu \mathrm{g} / \mathrm{g}$

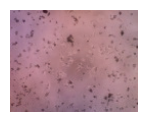

$125 \mu \mathrm{g} / \mathrm{g}$

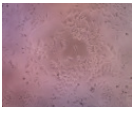

$15.6 \mu \mathrm{g} / \mathrm{g}$

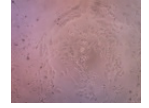

$31.25 \mu \mathrm{g} / \mathrm{g}$
T. decurrens

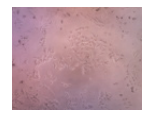

$62.50 \mu \mathrm{g} / \mathrm{g}$

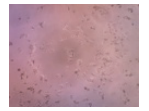

$125 \mu \mathrm{g} / \mathrm{g}$

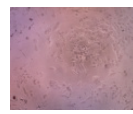

$250 \mu \mathrm{g} / \mathrm{g}$

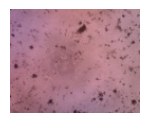

$250 \mu \mathrm{g} / \mathrm{g}$

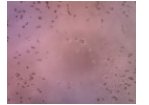

$250 \mu \mathrm{g} / \mathrm{g}$

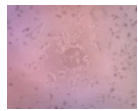

$500 \mu \mathrm{g} / \mathrm{g}$

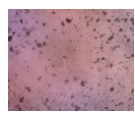

$500 \mu \mathrm{g} / \mathrm{g}$

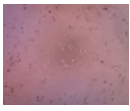

$500 \mu \mathrm{g} / \mathrm{g}$
Figure 2. The morphology of HeLa cells in (EE) of G. salicornia, T. decurrens, H. macroloba, and L. tronoi $(15.6,31.25,62.50,125,250$, and $500 \mu \mathrm{g} / \mathrm{g})$.

137.38, and $78.53 \mu \mathrm{g} / \mathrm{g}$ extracts, respectively, for G. salicornia, $T$. decurrens, H. macroloba, and L. tronoi.

The brown algae $T$. decurrens showed the best activity against cervical cancer cells. The most prevalent types of polysaccharides in the cell walls of different brown algae species are fucoidan and laminarins, which are the main reserve carbohydrates (Imbs et al., 2016). Currently, several experiments have yielded intriguing findings regarding the active cancer properties of fucoidan which were carried out in vivo and in vitro on different cancer types (Nishimoto, 2016). A brown alga, Sargassum boveanum, in hexane, trichloromethane, and butanol fraction presented cytotoxic activity against HeLa cell, each with $\mathrm{IC}_{50}$ values of $150.3 \pm 23.10,37.0 \pm 147.3$, and $110.4 \pm 33.67 \mathrm{mg} /$ $\mathrm{ml}$, respectively. The $\mathrm{IC}_{50}$ value of chloroform extract showed a value of $1,025.0 \pm 15.20 \mathrm{mg} / \mathrm{ml}$ (Rushdi et al., 2020).

Red alga $L$. tronoi showed cytotoxic activity against cervical cancer cells. Laurencia contains an abundance of structurally distinct secondary metabolites, which are characterized by an abnormally high level of halogenation and basic terpene structures. Laurenci's halogenated metabolites have a variety of biological properties, including anthelmintic, antifeedant, antifouling, antimalarial, antimicrobial, and cytotoxicity (Dias and Urban, 2011). Obtusol and elatol, two halogenated sesquiterpenes 
isolated from Laurencia dendroidea, showed a wide range of antiproliferative activity against colorectal adenocarcinoma cells (Colo-205) by inducing apoptosis (Marini et al., 2018). Terpenoids isolated from Laurencia tristicha and Laurencia nidifica have cytotoxic activity against $\mathrm{HeLa}$ cells with an $\mathrm{IC}_{50}$ value of 15.5 and 3.77 $\mu \mathrm{M}$, respectively (Rocha et al., 2018; Sun et al., 2007).

The green alga Halimeda macfoloba that has activity against HeLa cells has an average inhibitory activity of $55 \%$ in $15.6 \mu \mathrm{g} / \mathrm{ml}$ and tends to increase to nearly $75 \%$ at a concentration of $500 \mu \mathrm{g} / \mathrm{ml}$ extract under experimental conditions. Alkaloids isolated from seaweed, such as indole analog indole, 2-phenylethylamine, and 2,7-naphthyridine derivatives, especially those containing bromine and chloride, are predominantly present in chlorophyta (green algae). Bisindole caulerpine or caulerpine was isolated mainly from green algae genera Caulerpa sp., Codium decorticatum, and Halimeda incrassata (Rocca et al., 2018).

Gracilaria salicornia displayed the lowest inhibition $(30 \%-55 \%)$ in HeLa cell viability. Although G. salicornia extract in this study was not effective as an antiproliferative agent, other studies have shown that this seaweed has anticancer activity. Methanol extract of Gracilaria cornicata is used against carcinoma of the liver (HepG2) and breast (MCF-7). The mean inhibitory activity was $91 \%$ and $93 \%$ using $500 \mu \mathrm{g} / \mathrm{ml}$ extract. The $\mathrm{IC}_{50}$ values for methanol extract of $G$. cornicata against MCF-7, HeLa, MDA-MB-231, HepG2, and HT-29 cells were $30 \pm 0.2,37$ $\pm 0.2,53 \pm 0.5,102 \pm 0.2$, and $250 \pm 0.0 \mu \mathrm{g} / \mathrm{ml}$, respectively, after treatment for 24 hours (Ashwini and Shantaram, 2017).

Ghannadi et al. (2016) reported that G. cornicata had cytotoxic activity against cervical cancer cell with an $\mathrm{IC}_{50}$ of 125.9 $(\mu \mathrm{g} / \mathrm{ml})$. Currently, the use of $90 \%$ silver nitrate nanoparticles $0.1 \mathrm{M}$ in $10 \mathrm{ml}$ of $\mathrm{G}$. cornicata extract solution made into 100 $\mathrm{ml}$ has been shown to treat liver cancer (HepG2) (Supraja et al., 2016). The use of $\mathrm{Zn}$ in Gracilaria edulis extract has toxic activity against cervical cancer SiHa cells (Mohamed et al., 2019), also through the use of gold in making extracts of Sargassum aurum nanoparticles, which have shown to be effective against HeLa cells (Ajdari et al., 2016).

\section{Total phenolic content (TPC)PC}

The TPC for each seaweed is shown in Figure 3. The results show that the highest TPC is in L. tronoi, followed by $H$. macroloba, T. decurrens, and G. salicornia with values of 2.051 $\pm 0.43,1.911 \pm 0.19,1.165 \pm 0.103$, and $0.193 \pm 0.04 \mu \mathrm{g} \mathrm{GAE} / \mathrm{g}$ extract, respectively.

Phenolic compounds are composed of an aromatic ring containing one or more hydroxyl groups in a polymer structure. This compound exhibits a great deal of biological activity. The most common polyphenol subclasses in seaweed are phenol halogens, cathechins, flavonols, and phlorotannins. Phlorotannin is mostly found in brown algae, while bromophenol, a polyphenol compound with one or more bromine substituents, is most commonly found in red algae (Rocha et al., 2018).

According to Thomas and Kim (2011), the antiproliferative activity of seaweed is dependent on the polyphenol material. However, the chemical structure of seaweed's bioactive compounds is poorly understood, and scientific documents on bioactive compounds were scarce and unavailable until recently. As a result, we determined the phenolic content of the EE and

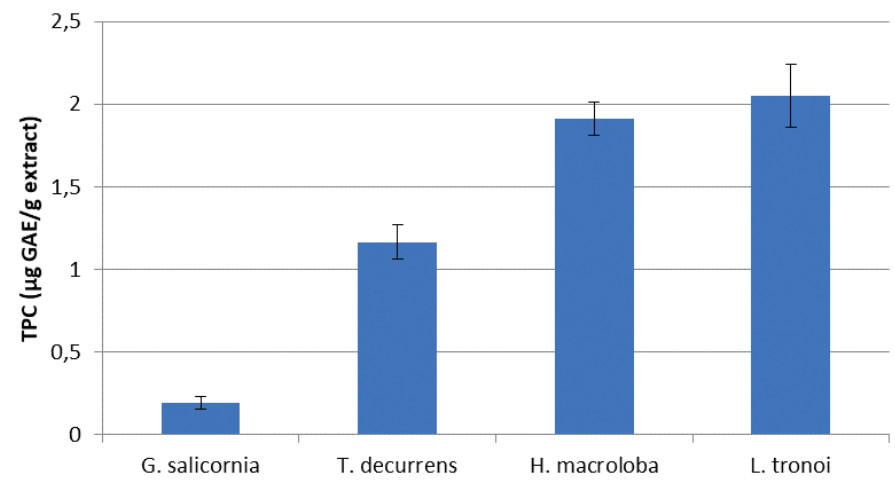

Figure 3. TPC of EE of G. salicornia, T. decurrens, H. macroloba, and L. tronoi

concluded that there was a correlation between the TPC of the EE and its cytotoxic activity. This relationship shows a positive correlation, because $T$. decurrens, H. macroloba, and L. tronoi, apart from having high TPC, also have high cervical anticancer activity, while $G$. salicornia has low TPC and low cervical anticancer activity. In general, phenolic compounds have physical, chemical, and biological activities that make them useful as drugs, including antimicrobial, anti-inflammatory, and anticancer properties (Deyab et al., 2016).

\section{DPPH FREE RADICAL SCAVENGING ACTIVITY}

The extract of five seaweeds exhibits DPPH-scavenging activity (Fig. 4), the most effective being $L$. tronoi, followed by $H$. macroloba, $G$. Salicornia, and $T$. decurrens, with the $\mathrm{IC}_{50}$ values of $0.48 \pm 0.023,1.33 \pm 0.96,2.88 \pm 0.24,3.794 \pm 0.25 \mathrm{mg} / \mathrm{ml}$, respectively.

The mechanism of the role of seaweed antioxidants is to strengthen the host defense system through increasing natural killer cells, inhibiting the complex process of angiogenesis and cell growth in the G1 phase, activating the nonspecific immune system, and inducing thermal differentiation and apoptosis, which is thought to be a factor in the inhibition of carcinogenesis. Many chronic illnesses, including cancer, have been treated with dietary fiber. As a result, dietary habits, especially increasing the consumption of antioxidant-rich functional foods, can help to reduce the risk of cancer (Namvar et al., 2014).

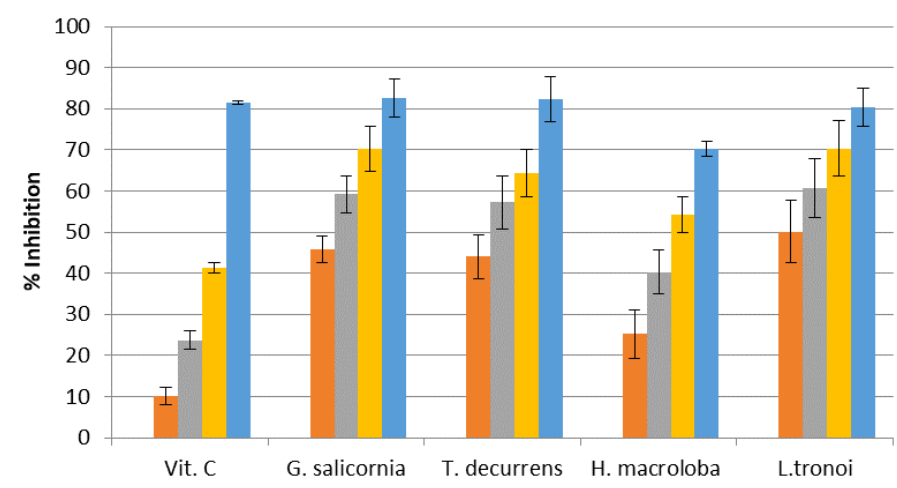

Figure 4. DPPH radical scavenging activity of $\mathrm{EE}$ of vitamin $\mathrm{C}(1.25,2.5,5$, and $10 \mu \mathrm{g} / \mathrm{g})$, G. salicornia $(2.5,5,7.5$, and $10 \mathrm{mg} / \mathrm{ml})$, T. decurrens $(2.5,5,7.5$, and $10 \mathrm{mg} / \mathrm{ml}), H$. macroloba $(0.5,1,1.5$, and $2 \mathrm{mg} / \mathrm{ml})$, and L. tronoi $(0.5,1$, 1.5 , and $2 \mathrm{mg} / \mathrm{ml}$ ) 


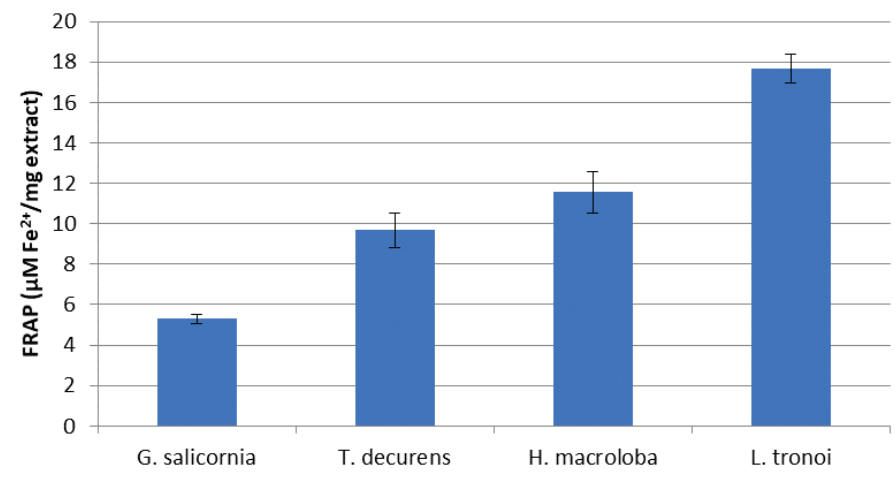

Figure 5. FRAP of EE of G. Salicornia, T. decurrens, H. macroloba, and $L$. tronoi.

\section{FERRIC REDUCING ANTIOXIDANT POWER (FRAP)}

The antioxidant activity of the compounds in the sample to reduce ferric (III) to ferrous (II) in the colorimetric redox reaction range is used to determine FRAP's antioxidant activity. FRAP is an electron donor and completes oxidation chain reactions through the reduction of oxidized intermediates to form a stable form (Sanger et al., 2013). Figure 5 shows that the highest reducing power was shown by $L$. tronoi extract with a concentration of $17.65 \pm 0.71 \mathrm{uM} \mathrm{Fe}^{2+} / \mathrm{mg}$ extract. Polyphenol is a reducing agent that, when combined with other reducing agents including vitamins $\mathrm{C}$ and $\mathrm{E}$ and carotenoids, protects body tissues from oxidative stress and related diseases like cancer (Tapiero et al., 2002).

Previous research has shown that the EE of Kappaphycus alvarezii has a stronger inhibitory effect than the antioxidant BHT. This is believed to be attributed to the algal extract's inclusion of ascorbic acid and vitamin A ( $\beta$-carotene) (Fayaz et al., 2005). Because of their ability to reduce electrons and quench the resulting oxidation, antioxidants can perform both primary and secondary roles (Sanger et al., 2013).

Marine products and their derivatives play a significant role in preventing inflammatory reactions and carcinogenesis through modulation of the effects of oxidative stress (Taskin et al., 2014). Various types of dietary antioxidants show amazing potential as compounds that are effective in preventing and treating chronic diseases through reduction of oxidative stress (Lobo et al., 2010). Polysaccharides and terpenoids in brown algae are considered potential bioactive molecules for cancer drugs. PUFAs are abundant in marine algae, and these compounds have been shown to slow the spread of breast cancer in the body (Wang et al., 2014; Imbs et al., 2016).

Some macroalgae sulfate polysaccharides (fucoidan, translam, and ulvan) reduce cell proliferation, while terpenes, for example, caulerpenynes from Caulerpa taxifolia, mediterraneol from Cystoseira mediterranea, and meroterpenes, usneoidone $\mathrm{E}$, and usneoidone $\mathrm{Z}$ from Cystophora usneoides, inhibit mitotic cell division. Sesquiterpene from $C$. taxifolia was found to be antiproliferative against $\mathrm{KB}$ cells and colorectal cancer lines (Ercolano et al., 2019). The red algae Plocamium corallorhiza and Phrynosoma cornutum contain polyhalogen monoterpene which can induce apoptosis in breast cell lines and induce necrosis. Desmosterol from green algae $G$. marginata exhibits cytotoxic activity against lymphocytic leukemia and human lung adenocarcinoma epithelial cell line. Various types of sterols from Porphyra sp. effectively control the proliferation of breast cancer cells line. Polysaccharide sulfate, fucoidan, from Sargassum muclurei extract shows anticancer activity against DLD-1 colon cancer cell line (Taskin et al., 2014). Antioxidants are recommended to anticipate carcinogenesis because of their ability to destroy reactive oxygen species causing irreparable DNA damage or incorrect repair resulting in mutations. Flavonoid antioxidants such as quercetin and apigenin are recognized as potential inhibitors of cell proliferation. Quercetin and apigenin have the potential to inhibit melanoma growth and metastatic in mice (Caltagirone et al., 2000). It was further reported that flavonoids stop angiogenesis in the human body. Angiogenesis inhibitors show a strong influence on various angiogenesis steps, such as endothelial cell proliferation and migration and lumen formation (Hsu and Wang, 2019; Rushidi et al., 2020).

HPV-16, which often causes squamous cell carcinoma, is the most carcinogenic HPV genotype. HPV-18 is primarily responsible for endocervical glandular adenocarcinoma, a cancer that is less frequently initiated but more aggressive. Cervical carcinogenesis, on the other hand, can arise from infections involving a variety of high risk forms that work together. The most important factor in HPV transmission is genital communication (McGraw and Ferrante, 2014). HeLa and SiHa cells are HPVpositive, and these two types of HPV in each cell are different; and HPV-18 is found in HeLa cells, while HPV-16 is found in SiHa cells (Gomes et al., 2015).

Seaweed has long been used traditionally in Asian diets and for extensive medicinal purposes for centuries. Currently, most of them are used as raw materials in the industry for many seaweed products such as jam, cheese, wine, tea, soup, and noodles (Ashwini and Shantaram, 2017). Some traditional Chinese medicines have strong anti-HPV properties and have been used to prevent and treat HPV-related cancers in China. The Chinese medicine Chaihu was reported to have significant inhibitory effects on HPV infection by limiting the expression of HPV growth in the genital region. By delaying the expression of HPV-DNA, Chinese medicine Youdujing can reverse the role of cervical lesions in high-risk HPV-infected patients (Xiao et al., 2012).

Marine heparinoid polysaccharides are similar in structure to heparin, a glycosaminoglycan group, including carbohydrates consisting of repeating disaccharide units containing alginate, ulvans, and their sulfate derivatives such as dextran sulfate and chitosan sulfate (Kang et al., 2016). Several previous studies have shown that several marine heparinoid polysaccharides, such as alginic acid and fucoidan, can effectively inhibit HPV pseudovirion infection (Wang et al., 2014). Furthermore, a report by Buck et al. (2006) stated that agar derivatives of sulfate polysaccharides can inhibit HPV Pseudomonas infection with an $\mathrm{IC}_{50}$ value of 0.27 $\mu \mathrm{g} / \mathrm{ml}$.

Carrageenan and dextrans structural derivatives like dextran can also boost the effectiveness of the HPV vaccine peptide. Carrageenan iota affects both in vivo and in vitro activity. Most of the sulfate compounds are very essential potent acting as anti-HPV from carrageenan (Zhang et al., 2010). Fucoidan produced from brown algae can destroy Pseudomonas in HPV infection in vitro with an $\mathrm{IC}_{50}$ value of $1.1 \mu \mathrm{g} / \mathrm{ml}$, despite the fact 
that the anti-HPV effect is not as strong as carrageenan $\left(\mathrm{IC}_{50}<0.1\right.$ $\mu \mathrm{g} / \mathrm{ml}$ ) (Hsu and Wang, 2019).

Carrageenan may be responsible for T. decurrens' anticancer activity because the TPC is low. Furthermore, $L$. tronoi had lower cervical anticancer activity than $T$. decurrens, but the highest TPC and antioxidant activity of DPPH and FRAP. Seaweed polyphenol compounds can function as chemopreventive substances because of their antioxidant properties. In times of stress, oxidative compounds can act in the initiation, promotion, and development of cancer (Catarino et al., 2017; Murphy et al., 2014). Namvar et al. (2014), reported that methanol extract of Sargassum ilicifolium with TPC $55.95 \pm 4.33 \mathrm{mg}$ GAE/100 $\mathrm{g}$ extract and antioxidant activity using the FRAP method of $37.05 \mathrm{mmol} \mathrm{Fe} \mathrm{Fe}^{2+} / 100 \mathrm{~g}$ dried extract can inhibit the proliferation of cervical cancer and breast cancer cells. The mean $\mathrm{IC}_{50}$ values for $\mathrm{HeLa}$ and MCF-7 cells were $45 \pm 0.9$ and $37 \pm 0.2 \mu \mathrm{g} / \mathrm{ml}$, respectively, after 72 hours of treatment. According to Okai et al. (1994), the anticarcinogenic and antiproliferative properties of algal polyphenols are due to their antitumor promotional activity against ornithine decarboxylase induction by the tumor promoter 12-O-tetradecanoylphorbol-13-acetate in BALB/c 3 T3 fibroblasts. Phlorotannins and their derivatives play important roles as anticancer metabolites, acting in various cancer characteristics such as proliferative signaling, metastasis, cell cycle, resistance to cell death, avoidance, angiogenesis, and avoidance of growth suppressors (Caterino et al., 2017; Li et al., 2011).

Cancer causes an increase in tissue oxidative stress, and while the majority of the damage caused by oxidative stress is repaired, the level of oxidative modified bases in DNA remains low. The product of DNA base oxidation is sufficient to produce a significant mutation. Administration of Eucheuma cottonii extract to mice significantly enhanced their oxidative status which contributed to the in vivo tumor suppression response (Namvar et al., 2012).

Drugs for cervical cancer therapy have been found, but they are very expensive, cause liver and kidney damage, and cause drug resistance when treated for a long time (McGraw and Ferrante, 2014). Turbinaria decurrens and L. tronoi, therefore, have the possibility of being used as safe sources of anti-HPV. More than 3,000 new compounds from marine organisms have now been identified and demonstrate good antitumor activities over the past three decades. Currently, the Food and Drug Administration (FDA) has licensed five marine product compounds for use as prescription drugs in the treatment of different cancers (Ercolano et al., 2019). The United States FDA has approved 1-beta-dArabinofuranosylcytosine or cytarabine for the treatment of many forms of cancer under the name Cytosar-U.

Chemoprevention with natural media is a strategy for preventing, delaying, or reversing human carcinogenesis. There are numerous anticancer mechanisms, including tumor cell apoptosis, nucleic acid biosynthesis, inducing DNA structure damage, inhibiting RNA synthesis, intercepting the transcript process, and protein synthesis and function. Induction of apoptosis and inhibition of proliferation can both play important roles in cancer control and prevention, according to cell biology perspective (Gomes et al., 2015). Therefore, it is critical to promote the development of new anticancer drugs with low toxicity and high efficacy. According to the findings of this study, L. tronoi can be used as a source of bioactive compounds for the prevention and treatment of cervical cancer.

\section{CONCLUSION}

In this study, anticancer activities of the extracts of G. salicornia, T. decurrens, H. macroloba, and L. tronoi were presented and discussed. The results showed that the seaweeds collected from North Sulawesi waters exhibited cytotoxic activity on HeLa cells. Referring to the $\mathrm{IC}_{50}$ value, T. decurrens and L. tronoi extracts showed the most effective anticervical cancer activity, with values of 41.027 and $78.53 \mu \mathrm{g} / \mathrm{g}$ extracts, respectively. However, TPC, DPPH, and FRAP analyses revealed that L. tronoi had the highest antioxidant activity. Thus, $L$. tronoi has the potential to be further investigated in order to identify new resources for the development of anti-HPV and related cancer agents, as a novel anticervical cancer drug candidate. Nevertheless, it is advised that the compounds which have the potential to act as anticancer of these seaweeds can be isolated and purified for effectiveness in an in vivo study.

\section{ACKNOWLEDGMENT}

Financial support for this study was provided by a grant from the Ministry of Research and Technology/National Research and Innovation Agency, Republic of Indonesia, through Basic Research Scheme (Contract No. 260/Sp2H/AMD/LT/ DRPM/2020).

\section{CONFLICT OF INTEREST}

The authors report no financial or any other conflicts of interest in this work.

\section{AUTHOR CONTRIBUTIONS}

All authors made substantial contributions to conception and design, acquisition of data, or analysis and interpretation of data; took part in drafting the article or revising it critically for important intellectual content; agreed to submit to the current journal; gave final approval of the version to be published; and agree to be accountable for all aspects of the work. All the authors are eligible to be an author as per the international committee of medical journal editors (ICMJE) requirements/guidelines.

\section{REFERENCES}

Ajdari Z, Rahman H, Shameli K, Abdullah R, Abd Ghani MA, Swee Yeap S, Abbasiliasi S, Ajdari D, Ariff A. Novel gold nanoparticles reduced by Sargassum glaucescens: preparation, characterization and anticancer activity. Molecules, 2016; 221(123):1-17.

Ashwini S, Shantaram M. A study on the ethanolic extracts of red seaweed Gracilaria corticata (J.Agardh) J. Agardh, to assess the antiproliferative activity and morphological characterization of apoptosis on HeLa cell lines. Int J Phytomedicine, 2017; 9(3):436-42.

Bayro AM, Manlusoc JK, Alonte R, Caniel C, Conde P, Embralino C. Preliminary chracterization, antioxidant and antiproliferative properties of polysaccharide from Caulerpa taxifolia. Pharm Sci Res, 2021; $8(1): 30-6$.

Bray F, Jacques FJME, Soerjomataram I, Siegel RL, Torre LA, Jemal A. Global cancer statistics 2018: GLOBOCAN estimates of incidence and mortality worldwide for 36 cancers in 185 countries. CA Cancer J Clin, 2018; 69(6):394-424.

Buck CB, Thompson CD, Roberts JN, Muller M, Lowy DR, Schiller JT. Carrageenan is a potent inhibitor of papillomavirus infection. PLoS Pathog, 2006; 2:69. 
Caltagirone S, Rossi C, Poggi A, Ranelletti FO, Natali PG, Brunetti M, Aiello FB, Piantelli M. Flavonoids apigenin and quercetin inhibit melanoma growth and metastatic potential. Int $\mathrm{J}$ Cancer, 2000; 87(4):595-600.

Catarino MD, Silva AMS, Cardoso SM, Fucaceae: a source of bioactive phlorotannins. Int J Mol Sci, 2017; 18(1327):1-30.

Corsetto PA, Montorfano G, Zava S, Colombo I, Ingadottir B, Jonsdottir R, Sveinsdottir K, Rizzo AM. Characterization of antioxidant potential of seaweed extracts for enrichment of convenience food. Antioxidants (Basel), 2020; 9(3):249; https://doi.org/10.3390/ antiox 9030249 .

Debbarama J, Rao BM, Murthy LN, Mathew S, Venkateshwarlu G, Ravishankar C. Nutritional profiling of the edible seaweeds Gracilaria edulis, Ulva lactuca and Sargassum sp. Indian J Fish, 2016; 63(3):81-7.

Deyab M, Taha E, Ward F. Qualitative and quantitative analysis of phytochemical studies on brown seaweed Dictyota dichotoma. Int J Eng Dev Res, 2016; 4(2):674-8.

Dias DA, Urban S. Phytochemical studies of the southern Australian marine alga, Laurencia elata. Phytochemistry, 2011; 72:2081-9.

Ercolano G, De Cicco P, Ianaro A. New drugs from the sea: pro-apoptotic activity of sponges and algae derived compounds. Mar Drug, 2019; 17(1):31.

Fayaz M, Namitha KK, Chidambara Murthy KN, Swamy M, Sarada R, Khanam S. Chemical composition, iron bioavailability, and antioxidant activity of Kappaphycus alvarezzi (Doty). J Agric Food Chem, 2005; 53:792-7.

Ganesan AR, Triwari U. Rajauria G. Seaweed and nutraceuticals and their therapeutic role in disease prevention. Food Sci Hum Well, 2019; $8(3): 252-63$.

Ghannadi A, Shabani L, Yegdaneh A. Cytotoxic, antioxidant and phytochemical analysis of Gracilaria species from the Persian Gulf. Adv Biomed Res, 2016; 5(1):139.

Gomes DL, Telles CBS, Costa MSSP, Almeida-Lima J, Costa LS, Keesen TSL, Rocha HAO. Methanolic extracts from brown seaweeds Dictyota cilliolata and Dictyota menstrualis induce apoptosis in human cervical adenocarcinoma HeLa cells. Molecules, 2015; 20(4):6573-6591.

Handayani D, Artasasta MA, Safirna N, Ayuni DF, Tallei TE, Hertiani T. Fungal isolates from marine sponge Chelonaplysilla sp.: diversity, antimicrobial and cytotoxic activities. Biodiversitas, 2020; 51(5):1954-60.

Handayani D, Sandrawati N, Ruslan R, Nestianda O, Fajrina A, Tallei ET. Cytotoxic and antimicrobial activities of ethyl acetate extract of mangrove plant Scyphiphora hydrophyllacea C. F. Gaertn - associated fungi. J Appl Pharm Sci, 2019; 9(6):75-9.

Hsu HY, Hwang PA. Clinical applications of fucoidan in translational medicine for adjuvant cancer therapy. Clin Transl Med, 2019; $8(1): 15$.

Imbs TI, Ermakova SP, Vishchuk, OSM, Isakov VV, Zvyagintseva TN. Structural elucidation of polysaccharide fractions from the brown alga Coccophora langsdorfii and in vitro investigation of their anticancer activity. Carbohydr Polym, 2016; 135:162-8.

Kang Y, Li H, Wu J, Xiaoting X, Sun X, Xiaodong Z, Nianjun X. Transcriptome profiling reveals the antitumor mechanism of polysaccharide from marine algae Gracilariopsis lemaneiformis. PLoS One, 2016; 11(6):1-16.

Kim SK, Wijesekara I. Development and biological activities of marine-derived bioactive peptides: a review. J Funct Foods, 2010; 2:1-9.

Korivi M, Chen CT, Yu SH, Ye W, Cheng IS, Chang JS, Kuo $\mathrm{CH}$, Hou $\mathrm{CW}$. Seaweed supplementation enhances maximal muscular strength and attenuates resistance exercise-induced oxidative stress in rats. Evid Based Complementary Altern Med, 2019; 2019:3528932; doi:10.1155/2019/3528932

Li YX, Wijesekara I, Li Y, Kim SK. Phlorotannins as bioactive agents from brown algae. Process Biochem, 2011; 46:2219-24.

Lobo V, Patil A, Phatak A, Chandra N. Free radicals, antioxidants and functional foods: impact on human health. Pharmacogn Rev, 2010; $4(8): 118-26$.
Maioli E, Torricelli C, Fortino V, Carlucci F, Tommassini V, Pacini A. Critical appraisal of the MTT assay in the presence of Rottlerin and uncouplers. Biol Proc Online, 2009; 11:227-40.

Majumder I, Chatterjee S, Kundu R. A study on anti-proliferative property of some green algae on human cervical cancer cells $(\mathrm{SiHa})$ in vitro. J Algal Biomass Util, 2015; 6:21-25.

Marini MB, Rodrigues de Freitas W, Lacerda da Silva Machado F, Leal ICR, Soares AR, Kanashiro MM, Muzitano MF. Cytotoxic activity of halogenated sesquiterpenes from Laurencia dendroidea. Phytother Res, 2018; 32:1119-25.

McGraw SL, Ferrante JM. Update on prevention and screening of cervical cancer. World J Clin Oncol, 2014; 5(4):744-52.

Mohamed ARB, Gowdhami B, Mohamed JMS, Archunan G, Suganthy N. Anticancer potential of zinc oxide nanoparticles against cervical carcinoma cells synthesized via biogenic route using aqueous extract of Gracilaria edulis. Mater Sci Eng C, 2019; 1003:109840.

Murphy C, Hotchkiss S, Worthington J, McKeown SR. The potential of seaweed as a source of drugs for use in cancer chemotherapy. J Appl Phycol 2014, 26:2211-64.

Namvar F, Baharara J, Mahdi AA. Antioxidant and anticancer activities of selected Persian Gulf algae. Indian J Clin Biochem, 2014; 29(1):13-20.

Namvar F, Mohamed S, Fard S. Polyphenol-rich seaweed (Eucheuma cottonii) extract suppresses breast tumour via hormone modulation and apoptosis induction. Food Chem, 2012; 130(2):376-82.

Nishimoto S. Clinical improvement in cancer patients through integrative medicine supplemented mainly with low-molecular fucoidan. J Int Soc Life Inf Sci, 2016; 34(2):153.

Okai Y, Higashi-Okai K, Nakamura S, Yano Y, Otani S Suppressive effects of the extracts of Japanese edible seaweeds on mutageninduced umu C gene expression in Salmonella typhimurium (TA 1535/pSK 1002) and tumor promotor-dependent ornithine decarboxylase induction in BALB/c 3T3 fibroblast cells. Cancer Lett, 1994; 87(1):25-32.

Pal R. Kundu R. Human papillomavirus E6 and E7: the cervical cancer hallmarks and targets for therapy. Front Microbiol, 2019; 10(3116):1-15.

Praiboon J, Palakas S, Noiraksa T, Miyashita K. Seasonal variation in nutritional composition and anti-proliferative activity of brown seaweed, Sargassum oligocystum. J Appl Phycol, 2018; 30:101-11.

Rocha HA, Seca AML, Pinto DCGA. Seaweed secondary metabolites in vitro and in vivo anticancer activity. Mar Drugs, 2018; 16(11):410

Rushdi MI, Abdel-Rahman IAM, Saber H, Attia EZ, Wedad M, Hashem A, Hassan, HM, Elmaidomy AH, Abdelmohsen UR Pharmacological and natural products diversity of the brown algae genus Sargassum. RSC Adv, 2020; 10:24951-24972.

Sandrawati N, Hati PS, Yunita F, Putra AE, Ismed F, Tallei TE, Hertiani T, Handayani D. Antimicrobial and cytotoxic activities of marine sponge-derived fungal extracts isolated from Dactylospongia sp. J Appl Pharm Sci, 2020; 10(4):28-33.

Sanger G, Rarung LK, Kaseger BE, Assa JR, Agustin AT. Phenolic content and antioxidant activities of five seaweeds from North Sulawesi, Indonesia. AACL Bioflux, 2019; 12(6):2041-950.

Sanger G, Widjanarko SB, Kusnadi J, Berhimpon S. Antioxidant activity of methanol extract of seaweeds obtained from North Sulawesi. Food Sci Qual Manag, 2013; 19:63-70.

Sun J, Shi DY, Wang SJ, Han LJ, Fan X, Yang YC, Shi JG. Chemical constituents of the red alga Laurencia tristicha. J Asian Nat Prod Res, 2007; 9:725-34

Supraja N, Pravad RNVK, Soundariya M, Babujanarthanan R. Syntesis, characterization and dose dependent antimicrobial and anticancerous activity of phycogenic silver nanoparticles against human hepatic carcinoma (HepG2). AIMS Bioeng, 2016; 3:425-40.

Sylvester PW. Optimization of the tetrazolium dye (MTT) colorimetric assay for cellular growth and viability. Methods Mol Biol, 2011; 716:157-68 
Tapiero H, Tew KD, Nguyen BG, Mathe G. Polyphenols: do they play a role in the prevention of human pathologies? Rev Biomed Pharmacol, 2002; 56(29):200-7.

Taskin EZ, Caki ZM, Ozturk M. Assessment of in vitro antitumoral and antimicrobial activities of marine algae harvested from the eastern Mediterranean Sea. Afr J Biotechnol, 2010; 9(27): 4272-4277.

Thomas NV, Kim SK. Potential pharmacological applications of polyphenolic derivatives from marine brown algae. Environ Toxicol Pharmacol, 2011; 32:325-35.

Wang SH, Zhang XS, Guan HS, Wang W. Potential anti-HPV and related cancer agents from marine resources: an overview. Mar Drugs, 2014; 12:2019-35.

Xiao J, Wu J, Yu B. Therapeutic efficacy of Youdujing preparation in treating cervical high-risk papilloma virus infection patients. Zhongguo Zhong Xi Yi Jie He Za Zhi, 2012; 32:1212-5.
Zhang YQ, Tsai YC, Monie A, Hung CF, Wu TC. Carrageenan as an adjuvant to enhance peptide-based vaccine potency. Vaccine, 2010 28:5212-9.

How to cite this article:

Sanger G, Rarung LK, Wonggo D, Dotulong V, Damongilala LJ, Tallei TE. Cytotoxic activity of seaweeds from North Sulawesi marine waters against cervical cancer. J Appl Pharm Sci, 2021; 11(09):066-073. 